\title{
Evaluation of Cardiac Functions and Electrocardiogram Parameters in Children with Celiac Disease
}

\author{
Çölyak Hastalı̆̆ı Olan Çocuklarda Kardiyak Fonksiyonların ve Elektrokardiyografik Parametrelerin Değerlendirilmesi
}

${ }^{1}$ Clinics of Pediatric Cardiology, Mersin Training and Research Hospital, Mersin,Turkey

${ }^{2}$ Clinics of Pediatric Gastroenterology, Mersin Training and Research Hospital, Mersin,Turkey

\section{Correspondence:}

Yasin ŞAHIN

Clinics of Pediatric Gastroenterology,

Mersin Training and Research

Hospital, Mersin,Turkey

e-mail: ysahin977@gmail.com

\section{Abstract}

We aimed to evaluate cardiac functions and electrocardiogram (ECG) parameters that are determinant in the development of atrial and ventricular arrhythmia in children with celiac disease.Twenty-eight patients with celiac disease followed up between March 2017 and June 2020 were evaluated retrospectively. 33 age-and sex-matched healthy children were included as the control group. Echocardiography (ECHO) and 12-lead ECG were performed in all patients and controls. Of the 28 patients, 16 were girls (57.1\%) and their mean age was $9.46 \pm 4.20$ years. The mean duration time of celiac disease was $2.17 \pm 2.21$ years. The Tp-e interval, QTc, QTc dispersion, and Tp-e / QT ratio were detected longer in celiac patients than in the control group $(\mathrm{p}<0.05)$. The patients were divided into 2 groups as seronegative (patients adhering to the gluten free-diet (GFD)) and seropositive celiac patients (patients not adhering to the GFD). There was no statistically significant difference between the two groups in terms of age and gender. The Tp-e interval, Tp-e / QT and Tp-e / QTc was determined longer in seropositive celiac patients. We found prolonged Tp-e interval, QTc, QTc dispersion and Tp-e / QT ratio in patients with celiac disease. In other words, we only detected the ventricular arrhythmia indicators as longer. In addition, we found prolonged Tp-e interval, Tp-e / QT and Tp-e / QTc in patients not adhering to a strict GFD. We detected that untreated celiac patients have a higher risk of ventricular arrhythmia. We think that further studies with more pediatric celiac patients who have longer duration of disease are needed for precise interpretation.

Keywords: cardiac function, celiac disease, echocardiography, electrocardiography
Çölyak hastalığı tanılı çocuk hastalarda atriyal ve ventriküler aritmi gelişiminde belirleyici olan elektrokardiyogram (EKG) parametrelerini ve kardiyak fonksiyonları değerlendirmeyi amaçladık. 2017 Mart-2020 Haziran dönemlerinde çölyak hastalığı tanısı ile takip edilen 28 hasta retrospektif olarak değerlendirildi. Yaş ve cinsiyet uyumlu 33 hasta kontrol grubu olarak alındı. Tüm hasta ve kontrol grubuna Ekokardiyografi (EKO) ve 12 kanallı elektrokardiyogram tetkiki yapıldı. Hastaların 16's1 kız (\%57,1)

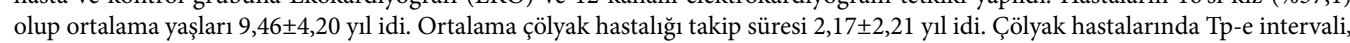
QTc, QTc dispersiyonu, Tp-e/QT ve Tp-e/QTc oranları kontrol grubuna göre daha uzun saptandı ( $<0.05$ ). Hastalar seronegatif (glutensiz diyete uyumlu) ve seropozitif (glutensiz diyete uyumsuz) çölyak hastaları olarak 2 gruba ayrıldı. Her iki grup arasında yaş ve cinsiyet yönünden istatistiksel olarak fark yoktu. Seropozitif hastalarda yani diyete uymayan hastalarda Tp-e intervali, Tp-e/ QT ve Tp-e/QTc daha uzun saptandı $(\mathrm{p}<0.05)$ Çölyak hastalarında Tp-e intervali, QTc, QTc dispersiyonu, Tp-e/QT oranlarını kontrol grubuna göre daha uzun saptadık. Diğer bir deyişle, sadece ventriküler aritmi göstergelerini daha uzun saptadık. Ayrıca glutensiz diyete uymayan hastalarımızda Tp-e intervali, Tp-e/QT ve Tp-e/QTc oranlarını daha uzun saptadık. Tedavi edilmemiş çölyak hastalarında ventriküler aritmi riskinin daha yüksek olduğunu tespit ettik. Daha kesin yorum yapabilmek için daha uzun takip sürelerine sahip daha fazla hasta içeren çalışmalara ihtiyaç olduğunu düşünüyoruz.

Anahtar Kelimeler: Çölyak hastalığı, ekokardiyografi, elektrokardiyografi, kardiyak fonksiyon 


\section{Introduction}

Celiac disease is an immune-mediated systemic autoimmune disease triggered by gluten intake in genetically susceptible individuals and characterized by the combination of various degrees of small bowel injury and gluten-dependent clinical manifestations (1). The seroprevalence of celiac disease and prevalence of biopsyproven celiac disease worldwide is reported to be $1.4 \%$ and $0.7 \%$, respectively (2).

It has been reported that cardiovascular diseases such as cardiomyopathy, autoimmune myocarditis, arrhythmias and subclinical cardiac dysfunction are more common in patients with celiac disease compared to the control group (3-11). Ongoing systemic inflammation and accompanying nutritional deficiency in celiac disease may cause impairment in cardiac functions and other organs $(12,13)$. The gluten-free diet has protective effect against autoimmune diseases (14). Because of that, early diagnosis of celiac disease is very important to prevent long-term complications.

There are limited studies about cardiovascular disease and rhythm disturbances in pediatric celiac disease (15-21). There are increasing number of recent studies reporting changes in cardiac functions in untreated celiac disease patients (9).

In the current study, we aimed to evaluate cardiac functions and electrocardiogram (ECG) parameters that are determinant in the development of atrial and ventricular arrhythmia in children with celiac disease.

\section{Material and Methods}

Twenty-eight patients with celiac disease followed up between March 2017 and June 2020 were evaluated retrospectively. Celiac disease was diagnosed with European Society for Pediatric Gastroenterology, Hepatology and Nutrition 2012 guideline by intestinal biopsy (1). Local Ethics Committee approved the current study (19.08.2020/48, Toros University, Mersin).

Patients with any previous concomitant heart disease, chronic disease, and malignancy were not included in the study. Seven patients with concomitant chronic diseases were excluded from the study. 33 age-and sex-matched healthy children were included as the control group.

Both patient and control groups were evaluated by the same experienced pediatric cardiologist. Echocardiography (ECHO) and 12-lead ECG were performed in all patients and controls. The QT interval was measured from the beginning of the QRS complex to the end of the T-wave. Corrected QT (QTc) interval was measured according to the heart rate $(\mathrm{QT} /(\mathrm{R}-\mathrm{R}$ interval). The Tp-e interval is defined as the interval from the peak of the $T$ wave to the end of the T-wave. The Tp-e/ QT ratio was measured from those parameters. QTc dispersion was determined according to the difference between the shortest and longest QTc interval durations. P wave interval was measured from the beginning of the $\mathrm{P}$ wave to the end of the $\mathrm{P}$ wave. $\mathrm{P}$ wave dispersion was determined according to the difference between the shortest and longest $P$ wave durations.

All patients were evaluated with transthoracic ECHO including 2D and color-Doppler imaging. Conventional ECHO measurements were done in accordance with the standards recommended by the American ECO Association. All patients' and healthy controls' hearts were evaluated through apical, parasternal long and short axis view (22). Ejection fraction (EF) was measured by modified Simpson's method (23).

\section{Statistical analysis}

Statistical analysis was performed using SPSS software version 20.0 (SPAA Inc, Chicago IL, USA). Descriptive statistics were used for frequency, percentage, and mean \pm standard deviation (SD). Independent samples t-test was used for nominal data. Chi-square test was used for comparison of categorical variables. Mann-Whitney U test or KruskalWallis test was used for parameters with nonnormal distribution. $\mathrm{P}$ value $<0.05$ was considered as statistically significant. 


\section{Results}

Of the 28 patients, 16 were girls $(57.1 \%)$ and their mean age was $9.46 \pm 4.20$ years. The mean duration time of celiac disease was $2.17 \pm 2.21$ years. The demographic characteristics and laboratory parameters of the patients are shown in table 1. Folate deficiency was detected in 2 patients. 14 patients had iron deficiency anemia.

Electrocardiographic and echocardiographic characteristics of the patient and control groups are shown in Table 2. There was no difference between the two groups in terms of age, gender, height and weight $(p>0.05)$. The Tp-e interval, QTc, QTc dispersion, and Tp-e / QT ratio were detected longer in celiac patients than in the control group $(\mathrm{p}<0.05)$ (Table 2).

The patients were divided into 2 groups as seronegative (patients adhering to a strict gluten free-diet (GFD) and seropositive celiac patients (patients not adhering to a strict GFD) (Table 3). There was no statistical difference between the two groups in terms of age and gender ( $\mathrm{p}>0.05)$. Tp-e interval, Tp-e / QT and Tp-e / QTc was determined longer in seropositive celiac patients $(\mathrm{p}<0.05)$ (Table $3)$.

Mitral valve prolapse (MVP) and minimal mitral regurgitation (MR) were detected in 4 patients $(14.3 \%)$ by conventional ECHO. No systolic or diastolic dysfunction was found in the patient and control groups.

\section{Discussion and Conclusion}

We have investigated cardiac functions and ECG parameters that are determinant in the development of atrial and ventricular arrhythmia in children with celiac disease. The Tp-e interval, QTc, QTc dispersion, and Tp-e / QT ratio were detected longer in celiac patients than in the control group. Tp-e interval, Tp-e / QT and Tp-e / QTc was determined longer in seropositive celiac patients.

Despite increased awareness of physicians about celiac disease and screening tests for celiac disease are performed in high-risk groups, a majority of celiac patients still remain undiagnosed $(24,25)$.

Although there are many studies reporting cardiac involvement in celiac disease, the mechanism of this involvement is not known exactly $(11,26,27)$. It has been suggested that nutritional deficiency secondary to chronic malabsorption in celiac disease may cause cardiomyopathy. In addition, various luminal antigens or infectious agents due to impaired intestinal permeability may cause myocardial damage by immune-mediated mechanisms $(15,28,29)$. As a result, direct immune response may cause damage in the small intestine and myocardium (30).

It has been reported that increased risk of atrial fibrillation is in patients with celiac disease. $(3,10,11,26,31)$. It has been suggested that systemic inflammation associated fibrotic changes in the atrium may play a role in the development of atrial fibrillation (11,30-34). In our study, we did not detect atrial fibrillation in any of our patients. For the development of atrial fibrillation, there should be fibrotic changes in the atrium. The long duration of disease is required for the development of fibrotic changes. Therefore, we may not have detected atrial fibrillation due to the young age of our patients and the short duration time of the disease. In addition to inflammation, hyperhomocysteinemia may lead to atrial fibrillation in patients with celiac disease. Homocysteine is an amino acid produced during the metabolism of methionine (35). In diseases such as celiac disease that cause folate deficiency, homocysteine metabolism is impaired and hyperhomocysteinemia occurs. It affects the sodium and potassium channels causing proarrhythmic effects in the atrium and so increases the risk of atrial fibrillation (36-38). It has been suggested that hyperhmocysteinaemia may play a role in the of atrial fibrillation in patients with celiac disease. In our study, folate deficiency was detected in 2 of our patients, but none of them had atrial fibrillation. The reason for this results may be the small sample size.

In a recent study, $\mathrm{P}$ wave, QT, QTc, Tp-e dispersion and Tp-e / QT ratio were found 
longer in patients with celiac disease than in the control group (19). In that study, there was no correlation between tissue transglutaminase antibody (tTG) levels and $\mathrm{P}$ wave, QT and Tp-e dispersion. No correlation was found with the duration of the disease. It has been suggested that the correlation might not have been found due to the short followup period. Also, it has been reported that celiac disease is associated with some ECG parameter changes that may be indicators of atrial and ventricular arrhythmia. In addition, it has been suggested that pediatric patients with celiac disease should be followed up regularly in terms of the risk of arrhythmia due to the long life expectancy (19). In an another study, it has been reported that Tp-e interval, Tp-e / QT and TP-e / QTc ratios are increased in patients with celiac disease, and further studies are needed to determine whether these changes increase the risk of ventricular arrhythmia (39). In that study, it has been reported that the Tp-e / QTc ratio is correlated with the duration of celiac disease. In accordance with those studies, we also found longer Tp-e interval, QTc, QTc dispersion and Tp-e / QT ratios in celiac disease patients compared to the control group $(19,39)$. Although parameters which are both atrial and ventricular arrhythmia indicators were detected longer in patients with celiac disease in the study of Demircan et al.(19), only ventricular arrhythmia indicators were detected longer in our study, the reason for this may be due to the small sample sizes and short follow-up period.

Karadeniz et al. found prolonged $\mathrm{P}$ wave duration and dispersion in patients with low iron stores (40). Iron deficiency anemia secondary to malabsorption is very common in patients with celiac disease. Demircan et al. detected prolonged $\mathrm{P}$ wave dispersion in pediatric celiac patients with low iron stores (19). In contrast to that study, we did not find prolonged $\mathrm{P}$ wave dispersion in any of the 14 celiac disease patients with low iron storage. Also, there was no difference between patients with low and normal iron stores in terms of $\mathrm{P}$ wave dispersion. Since myocardial damage has not yet developed by immune-mediated mechanisms, we may not have detected prolonged $\mathrm{P}$ wave dispersion.
Both QT and QTc dispersion can be used as a marker to determine the risk of ventricular arrhythmia (19). Previous studies have shown that prolonged QT and QTc dispersion are significantly correlated with ventricular premature beats in children with a structurally normal heart $(41,42)$. In a study including 83 adult celiac patients, prolonged QT was found in 33\% of celiac disease patients (8). Corazza et al. reported that prolonged QT is found especially in patients not adhering to a strict GFD, and suggested that the QT length should be regularly monitored in untreated celiac patients (8). In the current study, we detected prolonged QTc and QTc dispersion in patients with celiac disease compared to the control group. As consistent with those studies, we also detected prolonged QT in our patients not adhering to a strict GFD.

The Tp-e / QT ratio is not affected by heart rate and body weight, so it is used as a more sensitive marker than the TP-e and QT interval. The Tp-e / QT ratio is an important index in determining arrhythmogenic tendency in acquired and congenital channelopathies (43). Demirtaş et al. detected higher Tp-e interval and Tp-e / QT ratio in celiac disease patients compared to the control group, and also reported that the Tp-e / QT ratio is significantly higher as parallel with the disease duration (39). As consistent with that study, we also detected prolonged Tp-e interval and Tp-e / QT ratios in celiac disease patients. In contrast to that study, we found that the ratio of Tp-e / QT is significantly higher in patients not adhering to the GFD (p $<0.05$ ). We think that compliance with the treatment, not the duration of the disease, is more effective on the Tp e / QT ratio. When compliance with gluten-free diet is complete, systemic inflammation and immune response occur less likely in patients. Therefore, the possibility of damage to the small intestine and myocardium and the risk of arrhythmia occur less likely.

Rhythm disturbances secondary to electrolyte disturbance caused by malabsorption in celiac disease return to normal with gluten-free diet (44). None of our patients had electrolyte disturbances.

Left ventricular hypertrabeculation / 
noncompaction may be associated with celiac disease (45). In our study, we did not detect left ventricular hypertrabeculation/ noncompaction in any of the patients. The small number of our patients may be the reason of our results.

In a study including 40 celiac disease patients, mild cardiac involvement was found in 9 patients $(22.5 \%)$, mitral valve insufficiency in 5 patients, aortic valve insufficiency in 2 patients, pulmonary and tricuspid valve insufficiency in 1 patient, and low EF in 1 patient were detected (46). In addition, an improvement in cardiac changes was reported 12 months after GFD. In an another study including 60 pediatric celiac patients, moderate cardiac involvement (valve insufficiency or low EF) was found in 13 patients $(21.6 \%)$, and it has been shown that patients with celiac disease have lower contractility indexes (47). In that study, improvement in echocardiographic findings was observed after a gluten-free diet. In parallel with those studies, MVP and minimal MR were detected in 4 of our patients $(14.3 \%)$. However, we could not evaluate whether there is an improvement in cardiac changes after a gluten-free diet due to the short follow-up period.

A high prevalence of impaired left ventricular function has been reported in patients with celiac disease (48-50). Conversely, there are also studies reporting no systolic dysfunction by conventional ECHO $(16,19-21,51)$. In the present study, systolic dysfunction was not detected in any of our patients by conventional ECHO, but we think that studies with more patients are needed to make a more precise interpretation. In an another study, subclinical cardiac dysfunction was found in the majority of untreated celiac patients (18). In our study, no subclinical cardiac dysfunction was detected in any of our patients by conventional ECHO, and there was no subclinical cardiac dysfunction in patients not adhering to a strict GFD. Since the advanced ECHO examinations such as strain, strain rate and speckle tracking were not used, we may not have detected subclinical cardiac dysfunction.

Limitations of our study: First, lack of cardiac assessment results after adherence to the GFD. Due to the short follow-up period, we could not evaluate whether the patients have improvement in cardiac functions. Second, we have small sample size because the study is single-center. Third, advanced ECHO examinations such as strain, strain rate and speckle tracking may be more useful in detecting early and subclinical ventricular dysfunctions in patients with celiac disease, but we could not perform them.

In conclusion, we found prolonged $\mathrm{Tp}-\mathrm{e}$ interval, QTc, QTc dispersion and Tp-e / QT ratio in patients with celiac disease. In other words, we only detected the ventricular arrhythmia indicators as longer. We did not found prolonged atrial arrhythmia indicators in any of our patients. In addition, we found prolonged Tp-e interval, Tp-e / QT and Tp-e / QTc in patients not adhering to a strict GFD. We found that untreated celiac patients have a higher risk of ventricular arrhythmia. Further studies with more pediatric celiac patients who have longer duration of disease are needed to make a more precise interpretation.

\section{REFERENCES}

1. Husby S, Koletzko S, Korponay-Szabo IR, et al.; ESPGHAN Working Group on Coeliac Disease Diagnosis; ESPGHAN Gastroenterology Committee; European Society for Pediatric Gastroenterology, Hepatology, and Nutrition. European Society for Pediatric Gastroenterology, hepatology, and nutrition guidelines for the diagnosis of coeliac disease. $J$ Pediatr Gastroenterol Nutr 2012; 54: 136-60.

2. Singh P, Arora A, Strand TA, et al. Global prevalence of celiac disease: systematic review

and meta-analysis. Clin Gastroenterol 2018; 16: 823-36.

3. Bayar N, Çağırcı G, Üreyen ÇM, et al. The relationship between spontaneous multi-vessel coronary artery dissection and celiac disease. Korean Circ J 2015; 45: 242-244.

4. Wang I, Hopper I. Celiac disease and drug absorption: implications for cardiovascular therapeutics. Cardiovasc Ther 2014; 32: 253-256.

5. Curione $\mathrm{M}$, Barbato $\mathrm{M}$, Di Biase $\mathrm{L}$, et al. Prevalence of coeliac disease in idiopathic dilated 
cardiomyopathy. Lancet 1999; 354: 222-3.

6. Frustaci A, Cuoco L, Chimenti C, et al. Celiac disease associated with autoimmune myocarditis. Circulation 2002; 105: 2611-8.

7. Chimenti C, Pieroni M, Maseri A, et al. Dilated cardiomyopathy and celiac disease. Ital Heart $J$ 2002; 3: 385.

8. Corazza GR, Frisoni M, Filipponi $\mathrm{C}$, et al. Investigation of QT interval in adult coeliac disease. BMJ 1992; 304: 1285.

9. Ciaccio EJ, Lewis SK, Biviano $\mathrm{AB}$, et al. Cardiovascular involvement in celiac disease. World J Cardiol 2017; 9: 652-666.

10. West J, Logan RF, Card TR, et al. Risk of vascular disease in adults with diagnosed coeliac disease: a population based study. Aliment Pharmacol Ther 2004; 20: 73-79.

11. Emilsson L, Smith JG, West J, et al. Increased risk of atrial fibrillation in patients with coeliac disease: a nationwide cohort study. Eur Heart J 2011; 32: 2430-2437.

12. Schuppan D: Current concepts of celiac disease pathogenesis. Gastroenterology 2006; 119: 234242.

13. Ventura A, Magazzu G, Greco L. Duration of exposure to gluten and risk for autoimmune disorders in patients with celiac disease. SIGEP Study Group for Autoimmune Disorders in Celiac Disease. Gastroenterology 1999; 117: 297-303.

14. Cosnes J, Cellier C, Viola S, et al; Groupe D'Etude et de Recherche Sur la Maladie Coeliaque. Incidence of autoimmune diseases in celiac disease: protective effect of the gluten-free diet. Clin Gastroenterol Hepatol 2008; 6: 753-758.

15. Polat TB, Urganci N, Yalcin Y, et al. Cardiac functions in children with coeliac disease during follow-up: insights from tissue Doppler imaging. Dig Liver Dis 2008; 40: 182-187.

16. Saylan B, Cevik A, Kirsaclioglu CT, et al. Subclinical cardiac dysfunction in children with coeliac disease: Is the gluten-free diet effective? ISRN Gastroenterol 2012; 2012: 706937.

17. Fathy A, Abo-Haded HM, Al-Ahmadi N, et al. cardiac functions assessment in children with celiac disease and its correlation with the degree of mucosal injury: Doppler tissue imaging study. Saudi J Gastroenterol 2016; 22: 441-447.

18. Bolia R, Srivastava A, Kapoor A, et al. Children with untreated coeliac disease have sub-clinical cardiac dysfunction: a longitudinal observational analysis. Scand J Gastroenterol 2018; 53: 803808.

19. Demircan T, Appak YÇ, Baran M, et al. Does celiac disease effect electrocardiographic markers of arrhythmic events in children? J Pediatr Res 2021; 8: 7-13.

20. Deveci M, Uncuoğlu Aydoğan A, Altun G, et al. Left ventricular mechanics are affected in children with celiac disease: A study based on twodimensional speckle tracking echocardiography. Echocardiography 2017; 34: 1339-1346.

21. Karadaş U, Eliaçık K, Baran M, et al. The subclinical effect of celiac disease on the heart and the effect of gluten-free diet on cardiac functions. Turk J Pediatr 2016; 58: 241-245.

22. Sahn DJ, DeMaria A, Kisslo J, et al. Recommendations regarding quantitation in $\mathrm{M}$ - mode echocardiography: results of a survey of echocardiographic measurements. Circulation 1978; 58: 1072-83.

23. Folland ED, Parisi AF, Moynihan PF, et al. Assessment of left ventricular ejection fraction and volumes by real-time, two-dimensional echocardiography. A comparison of cineangiographic and radionuclide techniques. Circulation 1979;60:760-6.

24. Hujoel IA, Van Dyke CT, Brantner T, et al. Natural history and clinical detection of undiagnosed coeliac disease in a north American community. Aliment Pharmacol Ther 2018; 47: 1358-66.

25. Murch S, Jenkins H, Auth M, et al; BSPGHAN. Joint BSPGHAN and Coeliac UK guidelines for the diagnosis and management of coeliac disease in children. Arch Dis Child 2013; 98: 806-11.

26. Gajulapalli RD. Prevalence of atrial fibrillation in patient with celiac disease. Circulation 2014; 130 (Suppl 2): A12318.

27. Sari C, Bayram NA, Dogan FE, et al. The evaluation of endothelial functions in patients with celiac disease. Echocardiography 2012; 29: 471-7.

28. Van Elburg RM, Uil JJ, Mulder CJ, et al. Intestinal permeability in patients with coeliac disease and relatives of patients with coeliac disease. Gut 1993; 34: 354-7.

29. DeMeo MT, Mutlu EA, Keshavarzian A, et al. Intestinal permeation and gastrointestinal disease. J Clin Gastroenterol 2002; 34: 385-96.

30. Curione M, Barbato M, Viola F, et al. Idiopathic dilated cardiomyopathy associated with coeliac disease: the effect of a gluten-free diet on cardiac performance. Dig Liver Dis 2002; 34: 866-9.

31. Efe TH, Ertem AG, Coskun Y, et al. Atrial electromechanical properties in coeliac disease. Heart Lung Circ 2016; 25: 160-5.

32. Chung MK, Martin DO, Sprecher D, et al. Creactive protein elevation in patients with atrial arrhythmias: inflammatory mechanisms and persistence of atrial fibrillation. Circulation 2001; 104: 2886-2891.

33. Frustaci A, Chimenti C, Bellocci F, et al. Histological substrate of atrial biopsies in patients with lone atrial fibrillation. Circulation 1997; 96: 1180-1184.

34. Bayar N, Çekin AH, Arslan Ş, et al. Assessment of left atrial function in patients with celiac disease. Echocardiography 2015; 32: 1802-1808.

35. Nygard O, Vollset SE, Refsum H, et al. Total homocysteine and cardiovascular disease. J Intern Med 1999; 246: 425-454.

36. Cai BZ, Gong DM, Liu Y, et al. Homocysteine inhibits potassium channels in human atrial myocytes. Clin Exp Pharmacol Physiol 2007; 34: 851-855.

37. Cai B, Shan L, Gong D, et al. Homocysteine modulates sodium channel currents in human atrial myocytes. Toxicology 2009; 256: 201-206.

38. Hallert C, Grant C, Grehn S, et al. Evidence of poor vitamin status in coeliac patients on a glutenfree diet for 10 years. Aliment Pharmacol Ther 2002; 16: 1333-1339.

39. Demirtaş K, Yayla Ç, Yüksel M, et al. Tp-e interval and Tp-e/QT ratio in patients with celiac disease. Rev Clin Esp 2017; 217: 439-445. 
40. Karadeniz C, Özdemir R, Demirol M, et al. Low iron stores in otherwise healthy children affect electrocardiographic markers of important cardiac events. Pediatr Cardiol 2017; 38: 909-14.

41. Das BB, Sharma J. Repolarization abnormalities in children with a structurally normal heart and ventricular ectopy. Pediatr Cardiol 2004; 25: 3546.

42. Bluzaite I, Brazdzionyte J, Zaliunas R, et al. QT dispersion and heart rate variability in sudden death risk stratification in patients with ischemic heart disease. Med Kaunas 2006; 42: 450-4.

43. Gupta P, Patel C, Patel H, et al. Tp-e/QT ratio as an index of arrhythmogenesis. J Electrocardiol 2008; 41:567-74.

44. Callejas Rubio JL, Ortego N, et al. Celiac disease presenting as chronic anemia associated with heart block. Am J Gastroenterol 1998; 93: 1391-1392.

45. Stöllberger C, Finsterer J. Ischemic stroke in left ventricular noncompaction and celiac disease. Int J Cardiol 2014; 176: 534-536.

46. Lionetti E, Parisi G, Sciacca P, et al. Cardiac involvement in children with coeliac disease and the effect of gluten free diet on cardiac performance. Dig Liver Dis 2006; 38: 87-120.

47. Lionetti E, Catassi C, Francavilla R, et al. Subclinic cardiac involvement in paediatric patients with celiac disease: a novel sign for a case fnding approach. J Biol Regul Homeost Agents 2012; 26: S63-8.

48. Wei L, Spiers E, Reynolds N, et al. The association between coeliac disease and cardiovascular disease. Aliment Pharmacol Ther 2008; 27: 514-9.

49. Goel NK, McBane RD, Kamath PS. Cardiomyopathy associated with celiac disease. Mayo Clin Proc 2005; 80: 674-6.

50. Poddar B, Shava U, Srivastava A, et al. Severe heart failure, dilated cardiomyopathy and pulmonary haemosiderosis in coeliac disease: report of two cases. Paediatr Int Child Health 2014; 34: 142-144.

51. Cenk S, Aylin DB, Fatma Ebru A, et al. Assessment of lef ventricular function by strainstrain rate echocardiography in patients with celiac disease. Turk J Med Sci 2014; 44: 173177.

@Copyright 2021 by Osmangazi Tıp Dergisi - Available online at tip.ogu.edu.tr @Telif Hakkı 2021 ESOGÜ Tıp Fakültesi - Makale metnine dergipark.org.tr/otd web sayfasından ulaşılabilir. 